\section{Metabolism of Ciliary Body in Relation to Formation of Aqueous Humour}

THE oxidative metabolism of the ciliary body has been investigated with regard to the energy source for the secretion of aqueous humour. It has been shown previously that formation of aqueous humour is dependent on activo secretion of $\mathrm{Na}^{+}$(ref. 1) and there is some evidence that this process is effected by means of a sodium-potassium stimulated ATPase ${ }^{2-4}$, a finding in keeping with results on other secretory tissues ${ }^{5,6}$. The source of ATP or other high-energy intermediates utilized in $\mathrm{Na}^{+}$secretion must be from glycolysis or the citric acid cycle, as de Roetth ${ }^{7}$ has shown that the oxidized substrates of ciliary body are chiefly carbohydrate. Cole ${ }^{8}$ has shown that certain enzymes of the citric acid cycle are present in the epithelial cells and that succinic dehydrogenase is concentrated in the non-pigmented layer.

Bovine eyes, removed and chilled immediately after killing, were used within a period of $2 \mathrm{~h}$. Only the tips of the ciliary processes were used, giving a high proportion of epithelial cells to stromal tissue. Incubations were in a phosphate buffer with an atmosphere of 100 per cent oxygen, conditions which gave high rates of oxygen uptake, as was previously found by de Roetth?

Table 1. HFFeT of SUBSTRATES ON OXYGEN UPTAKE AND LACTATE Pronuction BY CiLIARY PRocesses

\begin{tabular}{lcc}
\multicolumn{1}{c}{ Additions } & $\begin{array}{c}\text { Oxygen uptake } \\
(\mu \mathrm{l} . / \mathrm{h} / C B)\end{array}$ & $\begin{array}{c}\text { Lactate } \\
(\mu \mathrm{M} / \mathrm{h} / C B)\end{array}$ \\
None & 39 & $0 \cdot 2$ \\
Glucose & 38 & $1 \cdot 7$ \\
Succinate & 66 & $0 \cdot 3$ \\
Glucose + succinate & 70 & $2 \cdot 0$ \\
Glucose + pyruvate & 38 & $2 \cdot 1$ \\
Glucose + fumarate & 48 & $1 \cdot 6$ \\
Glucose + pyruvate & 59 & $1 \cdot 6$
\end{tabular}

Tips of beef ciliary processes were obtained as a ring of tissue, a quarter of which was used per flask $(C B)$, approx. 40 ny wet wt. Medium was comprised of $\mathrm{Na}_{8} \mathrm{HPO}_{4}, 17.5 \mathrm{mM} ; \mathrm{KH}_{2} \mathrm{PO}_{4}, 4 \mathrm{mM} ; \mathrm{NaCl}, 98 \mathrm{mM} ; \mathrm{KCl}$, $27 \mathrm{mM}$; $\mathrm{MgSO}_{4}, 1.2 \mathrm{mM} ; ~ p \mathrm{H} \mathrm{7.4}$. Final volume, 1 inl.; gas phase, oxygen;

merature, $37^{\circ}$. Glucose was $3.0 \mathrm{mM}$, and other substrates $20 \mathrm{mM}$.

Table 1 shows the effects of various substrates on the rate of oxygen uptake and lactic acid formation of ciliary processes. Glucose, at concentrations up to $5.5 \mathrm{mM}$, did not increase the oxygen uptake rate above the endogenous rate, but greatly increased the amount of lactic acid produced. This suggests that the glycolytic enzymes were capable of a greater turnover than the rate at which oxidative metabolism could proceed. However, addition of succinate doubled the oxygen uptake rate, though pyruvate had no effect. This indicates that the entry of pyruvate into the citric acid cycle was limited by the availability of oxalacetate, and this was confirmed by the stimulation of oxygen uptake on the addition of fumarate together with pyruvate.

Table 2. Carbon Dioxide Production from ${ }^{14} \mathrm{C}-\mathrm{Glu}$.

\begin{tabular}{lc}
\multicolumn{2}{c}{ Processes } \\
Substrate & $\mathrm{CO}_{2}$ (c.p.m.) \\
${ }^{14} \mathrm{C}-1$-glucose & 1,675 \\
${ }^{14} \mathrm{C}-6$-glucose & 1,247 \\
${ }^{14} \mathrm{C}-1$ + pyruvate & 1,734 \\
${ }^{14} \mathrm{C}-6$ + pyruvate & 224
\end{tabular}

Incubation conditions were as in Table 1 , with $2-\mu$ c. ${ }^{14} \mathrm{C}$ per flask.

Experiments in Table 2, with labelled ${ }^{14} \mathrm{C}$-glucose, show that exogenous glucose was metabolized as far as carbon dioxide and not solely to lactic acid. As this caused no ehange in oxygen uptake rates, endogenous respiration was possibly maintained by glucose utilization. Further evidence was obtained when it was found that malonate inhibited both endogenous and glucose-supported respiration to the same extent and did not affect the lactate formation in either case.

There is little glucose present in the processes themselves, but the stromal tissue contains larger quantities. However, in view of the extensive blood supply of the ciliary body, numerous vessels extending right to the tips of the processes ${ }^{9}$, it is probable that the epithelial cells always have an abundant supply of glucose and that lactic acid is produced in vivo in quantities comparable with those found in vitro when glucose has been added to the incubs. tion medium. It has been postulated that the high lactic acid content of the aqueous humour results from the largely glycolytic metabolism of the lens and from the endothclium of the cornea ${ }^{10}$, but the results shown here indicate that this third source may make a significant contribution.

Results with ${ }^{14} \mathrm{C}-1$ - and ${ }^{14} \mathrm{C}-6$-glucose indicate that the hexose monophosphate shunt operates in the ciliary epithelium. 'The low activity of carbon dioxide from ${ }^{14} \mathrm{C}$-6-glucose in the presence of pyruvate is attributed to a dilution of the labelled acetyl-CoA entering the citric acid cycle. In the case of ${ }^{14} \mathrm{C}$-1-glucose the same effect is overshadowed by the stimulation by pyruvate of labelled carbon dioxide production via the hexose monophosphate shunt as described by Kinoshita ${ }^{11}$. Preliminary examination of the labelled products after incubation with ${ }^{-}{ }^{14} \mathrm{C}$-glucose shows that in tissue extracts there are quantities of labelled glutamate and aspartate present. It appears possible that the conversion of citric acid cycle intermediates into amino-acids may cause only a low concentration of oxalacetate to bo available for reaction with acetyl $\mathrm{CoA}$, thus limiting the turnover rate of the cycle.

Although Ballintine and Waitzman ${ }^{12}$ demonstrated ATP formation by ciliary processes oxidizing succinate it seems probable, in view of the apparently low turnover rate of the citric acid cycle when glucose is substrate, that the energy utilized for active transport by the epithelium is derived chiefly from a high rate of aerobic glycolysis.

\section{V. RILEy \\ V. BARONCELII}

Department of Physiology,

Institute of Ophthalmology, London, W.C.1.

${ }^{1}$ Cole, D. F., Brit. J. Ophthal., 45, 641 (1961). Bonting, S. L., Simon, K. A., and Hawkins, N. M., Arch. Biochem. Biophys.
(1961).

${ }^{3}$ Becker, B., Invest. Ophthal., 2, 325 (1963).

4 Riley, M. V., Exp. Eye Res. (in the press).

${ }^{5}$ Skou, J. C., Biochim. Biophys. Acta, 42, 6 (1960).

- Dunham, E. T., and Glynn, I. M., J. Physiol., 156, 274 (1961).

'De Roetth, A., Arch. Ophthal., 50, 491 (1953).

${ }^{8}$ Cole, D. H'., Exp. Eye Res., 2, 284 (1963).

- Scullica, L., Amer. J. Ophthal., 54, 1057 (1962).

${ }^{10}$ Davson, H., The Eye, edit. by Davson, H., 1 (Academic Press, London, 1962).

${ }^{11}$ Kinoshita, J. H., J. Biol. Chem., 228, 247 (1957).

${ }_{12}$ Ballintine, E. J., and Waitzman, M., Amer. J. Ophthal., 42,349 (1956).

\section{Determination of Small Amounts of Carbon-14 in the Presence of Large lodine-131 Activities, and an Experimental Estimation of the Specific Activities of (13I)-lodotyrosines}

IN the examination of mechanisms of chemical reactions, and particularly in biochemical studies of this nature, radioactive tracer substances of high specific activity are needed. In many cases it is desirable to use doubly labelled tracers containing carbon-14 or tritium as well as iodine-131. Recently, in an investigation of thyroid hormones ( $\left.{ }^{131} \mathrm{I}\right)$-iodotyrosines of very high specific activity were prepared by Reith and Tampion ${ }^{1}$. As the specific activity of these compounds could only be calculated from uncertain values, it was necessary to attempt an experimental determination using ${ }^{14} \mathrm{C}$-tyrosine in the iodination procedure. However, even using a carbon-14 substance of the highest obtainable specific activity, the iodino-131 activity is so much highor that their simultaneous counting becomes an extremely difficult if not an impossible task. Taking the specific activity of carbon-14 tyrosine as $20 \mathrm{mc} . / \mathrm{m}$.mole, an average iodination would give a rolation of $0.01 \mu \mathrm{c}$. carbon-14 for $500 \mu \mathrm{c}$. iodine-131; that is, a ratio of activitics of approximately $1: 50,000$ on liquid scintilla- 